\title{
Polyphase deformation in the Mbé - Sassa-Bersi area: Implications on the tectono-magmatic history of the area and the tectonic evolution of the Tcholliré-Banyo and Central Cameroon Shear Zones (Central North Cameroon)
}

\author{
Saha Fouotsa Alliance Nicaise ${ }^{1, *}$, Tchameni Rigobert ${ }^{1}$, Nomo Negue Emmanuel ${ }^{2}$, Daouda Dawai ${ }^{3}$, \\ Penaye Joseph ${ }^{4}$, Fosso Tchunte Periclex Martial ${ }^{1}$ \\ ${ }^{1}$ Department of Earth Sciences, Faculty of Science, University of Ngaoundéré P.O. box 454 Ngaoundéré, Cameroon \\ ${ }^{2}$ Department of Earth Sciences, Faculty of Science, University of Yaoundé I, P.O. box 812 Yaoundé, Cameroon \\ ${ }^{3}$ Department of Earth Sciences, Faculty of Sciences, University of Maroua, P.O. Box 55, Maroua, Cameroon \\ ${ }^{4}$ Centre de Recherches Géologiques et Minières (CRGM) de Garoua, P.O. Box 333 Garoua, Cameroun \\ *Corresponding author: nicsaha@yahoo.fr
}

\begin{abstract}
Field petrographic and structural data of the Mbé-Sassa-Bersi area exposed two main group of rock (metamorphics and plutonics) which were affected by polyphase deformation. The structural evolution is marked by four deformation phases called $D_{1}, D_{2}, D_{3}$ and $D_{4}$. The geometrical arrangement of $D_{1}$ structures (flat-lying foliation, horizontal lineation, recumbent folds and overlapping) allow to linked this deformation phase to tectonic nappe verging toward SSE. The second deformation stage $\left(\mathrm{D}_{2}\right)$ corresponds to simple shear dominated transpression and characterized by the evolution of the Tcholliré-Banyo shear zone (TBSZ) that showing sinistral movement. The third deformation phase $\left(\mathrm{D}_{3}\right)$, is marked by strain partitioning induced by transpression and links to the evolution of the Central Cameroon shear zone (CCSZ) that displays dextral motion. $\mathrm{D}_{1}, \mathrm{D}_{2}$ and $\mathrm{D}_{3}$ are associated to migmatization, development and emplacement of granitic magmatism. During $\mathrm{D}_{2}$ and $\mathrm{D}_{3}$, the magmatic rocks are emplaced under the control of the two main crustal shear zones (TBSZ and CCSZ). $\mathrm{D}_{4}$ deformation is responsible for the development of faults, fracture and joints and corresponds to brittle tectonic. The main NW-SE direction of faults and fractures suggest that $\mathrm{D}_{4}$ stage shows traces of the Benue trough. On the whole, Nappe tectonic, followed by transpressive tectonic are the main tectonic type developed during the Pan-African Orogeny in Central North Cameroon.
\end{abstract}

Keywords: Central African orogenic belt, central Cameroun domain, shear zone, nappe tectonic, transpression, strain portioning

Cite This Article: Saha Fouotsa Alliance Nicaise, Tchameni Rigobert, Nomo Negue Emmanuel, Daouda Dawaï, Penaye Joseph, and Fosso Tchunte Periclex Martial, "Polyphase deformation in the Mbé-Sassa-Bersi area: Implications on the tectono-magmatic history of the area and the tectonic evolution of the Tcholliré-Banyo and Central Cameroon Shear Zones (Central North Cameroon).” Journal of Geosciences and Geomatics, vol. 6, no. 2 (2018): 41-54. doi: 10.12691/jgg-6-2-2.

\section{Introduction}

Structural analysis of metamorphic and magmatic terranes is commonly used to characterise the tectonic evolution, define magmatism and deformation history in the orogens [1,2,3,4]. The Central African Orogenic Belt (CAOB; Figure 1a) also called the North Equatorial Fold Belt $[1,5,6]$ result from the convergence and collision between the Congo-São Francisco cratons, West African craton and Saharan metacraton [7,8,9,10]. In Cameroon, this orogenic Belt have been subdivided into three lithotectonics domains on the basis of petrographical, structural, geochronological and isotopic features [2,9,11]. These domains are from the south to the north, (1) the southern domain also called the Yaoundé domain, (2) the Central Cameroon domain or Adamawa-Yadé domain and (3) the Northern domain or North-West Cameroon domain (Figure 1b). The evolution of the CAOB involves many Pan-African shear zones among which the Tcholliré-Banyo shear zone (TBSZ) and the Central Cameroon shear zone (CCSZ) [2,9,10,12]. Several geological investigations were made on these shear zones with a view to understand their kinematic, tectonic regime and tectonic evolution [1,13]. Particularly, the Tcholliré-Banyo shear zone and the Central Cameroon shear zone are well investigated in the Tcholliré-Buffle Noir and Mayo 
Dana-West of Tibati regions respectively [1,14,15,16,17]. These investigations show $\mathrm{D}_{2}$ sinistral transpresion along the Tcholliré-Banyo [17]; $\mathrm{D}_{2}$ sinistral transpression (resulting from the interaction between shear and thrust movements) and $\mathrm{D}_{3}$ dextral transtension (resulting from interaction between shear and oblique normal fault movements) along the Central Cameroon shear zone [10]. However these previous results, shows some controversial regarding the kinematics, tectonic evolution and tectonic regime of these shear zones. For example, according to [14] and [16], structural analysis of the Tcholliré-Banyo shear zone reveals $\mathrm{D}_{2}-\mathrm{D}_{3}$ dextral transpression. In addition, the evolution of deformation is still discussed in the central north Cameroon. Some standpoint are in favour of two deformation phases $[18,19]$ while other point out four deformation phases [9,14,20,21,22,23,24]. More again, there are not consensual about the nature of structural elements that characterize each of the deformation phases. The Mbé - Sassa-Mbersi areas, where cross both shear zones is still studied out except some scarce structural studies made in the Ndom, Karna and Mbé areas $[9,10,16,25]$ to the west of the study areas. There is a need of field data providing detailed informations on the evolution of tectonic structures and the history of deformation. The aim of this works is to present field petrographical and structural data of the Mbé - Sassa-Mbersi area in order to (1) characterize the tectono-magmatic history, and (2) define the tectonic evolution of the Tcholliré-Banyo and Central Cameroon shear zones from the study of the portions of these shear zones in this area.

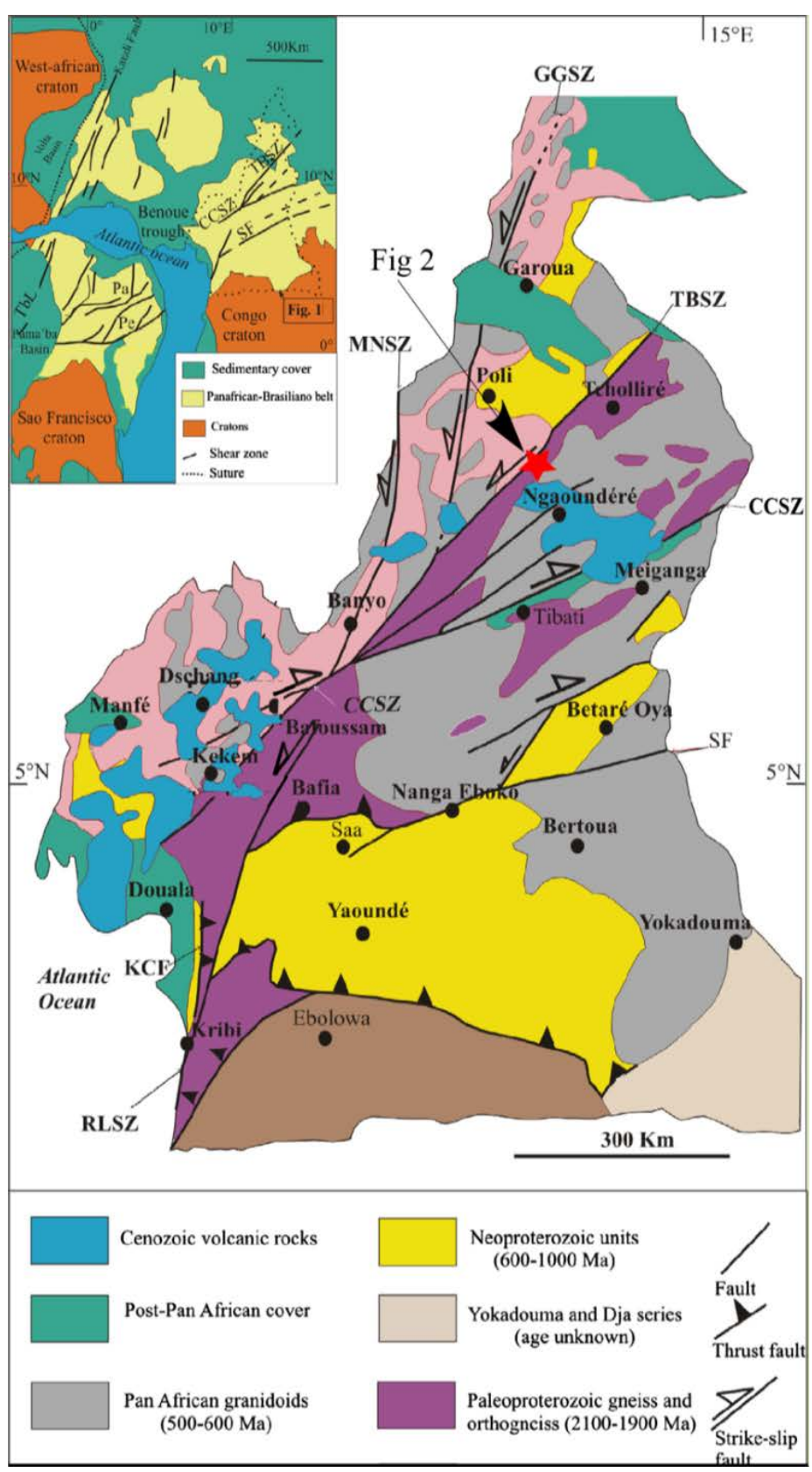

Figure 1. (a) Geological sketch map of west-central Africa and north-east Brazil with cratonic masses and the Pan-African-Brasiliano provinces belt in west-Gondwana; modified from Castaing et al. (1994) and Abdelsalam et al. (2002). TBSZ: Tcholliré-Banyo shear zone, CCSZ: Central Cameroon shear zone, SF: Sanaga fault, CCSZ: Central Cameroon shear zone, Pa: Patos shear zone, Pe: Pernambuco shear zone. Dashed outline roughly marks the state boundary of Cameroon. (b) Geological sketch map of Cameroon showing from the major lithotectonic domains (After Toteu et al., 2001 and Ngako et al., 2008). GGSZ: Godé-Gormaya shear zone, MNSZ: Mayo Nolti shear zone, RLSZ: Rocher du Loup shear zone. The red star corresponds to the study area. 


\section{Geological Setting}

The Mbé - Sassa-Mbersi area is located at around 60 $\mathrm{km}$ to the North of the Ngaoundéré town. It is geologically situated at the northern edge of the Central Cameroon domain of the Central African Orogenic belt, between the Tcholliré-Banyo shear zone to the North and the Central Cameroon Shear zone to the South (Figure 1).

The Tcholliré-Banyo shear zone (TBSZ) is a NE-SW Pan-African transcurrent shear zone of the CAOB in the northern Cameroon. It is marked by the heavy gravity anomaly, interpreted to underline a lithospheric scale suture [26,27]. The TBSZ is associated to (1) the Rey-Bouba greenstone belt (RBGB); [28] himself closely related to the low to high grade Poli Belt that continues beyond the Chadian border by the greenschists Gouey-goudoum Belt and Bibemi-Zalbi Belt; (2) the mylonitic hornblende-biotite gneiss of Mbé [25] on the south west prolongation of the this shear zone and (3) the Tcholliré batholith [17]. The RBGB is made of mafic to intermediate and felsic metavolcanic rocks; and by metasedimentary rocks all metamorphosed under low grade at $600 \mathrm{Ma}[28,29]$. The RBGB is actually considered as remnants of back arc basin [30,31] related to the TBSZ. The mylonitic hornblende-biotite gneiss of Mbé quarry which have been dated at $580 \pm 11 \mathrm{Ma}$ (U-Pb titanite age) was interpreted as dating the minimum age of sinistral deformation event in this area [25]. The Tcholliré batholith is hosted in the Rey-Bouba green schists and had been reported as syn-tectonic [14,17]. This massif consist of granites, emplaced during sinistral transpression between $632 \pm 13 \mathrm{Ma}$ and $719 \pm 12 \mathrm{Ma}$, period during which, the TBSZ was active in the Tcholliré area [14,17].

The ENE-WSW trending Central Cameroon Shear Zone (CCSZ) extends towards the Gulf of Aden [32] and is considered as the NW extension of the Pernambuco Fault in NE Brazil [3,33]. This shear zone marks the transition between a subdomain with an N-S trending foliation to the North and a subdomain with an E-W trending foliation to the South [15]. Along this shear zone and his Sanaga shear zone relay, kinematic analysis show an earlier $D_{2}$ sinistral transpression followed by a $\mathrm{D}_{3}$ dextral shear movement during Pan-African Orogeny [1].

The Central Cameroon domain that extends from the north of Sanaga shear zone (Figure $1 b$ ) to the South of the TBSZ [9] is made of (a) Palaeoproterozoic orthogneisses and metasediments, with abundant inherited zircon pointing to the significant contribution of an Archaean crust $[34,35,36,37,38]$. These rocks are dominantly migmatitic and transformed under high-pressure granulitic metamorphism dated at $600 \mathrm{Ma}$ [39,40]; (b) Neoproterozoic metavolcano-sedimentary rocks belonging to the Lom series, and recrystallized under low- to medium-grade metamorphic conditions during the Pan-African orogeny [1,31,41]; and (c) syn- to late-orogenic, weakly deformed granites emplaced at ca. 600 Ma [42,43], showing calc-alkaline to shoshonitic affinity [18,19,37], and considered to be of crustal or mixed origin $[41,43]$. The abundance of inherited zircon and monazite grains with
Archean to Paleoproterozoic $\mathrm{U}-\mathrm{Pb}$ ages in the metasediments and granites suggests that the Central Cameroon domain is mostly composed of rocks issued from an Archean to Paleoproterozoic crust reworked during the Pan-African orogeny [9,34]. According to [44] and [45], this domain represent an Archaean/Palaeoproterozoic crust, detached from the northern marging of the Congo craton during the early Neoproterozoic and re-accreted with the MayoKebbi domain during the Pan-African orogeny.

\section{Methodology}

In this study, we use classical field methods. The structural elements of each deformation phase are recognizable on the field and their orientation (strike and dip) were measured using compass and clinometer. Geometric analysis consisted of description and definition of groups of structures as proposed by [46]. These data were statistical analysed in the laboratory using Stereonet software. To get the overall orientation of the foliation, schistosity and lineation, the poles of these structural elements have been plotted and contoured in lower hemisphere of Schmidt diagrams using conventional techniques [47]. The deformation history and kinematic analysis of the whole area were deduced from the field study and detailed mapping of foliation and lineation trajectories in addition to observation of meso- to macroscopic criteria of coaxial or non-coaxial deformation. Thin sections of metamorphic and plutonic rocks have been observed at the Laboratoire de Cartographie, Pétrologie, Géochimie et Métallogénie (LCPGM) of the university of Ngaoundéré.

\section{Results: Petrography and Structure}

The Mbé - Sassa-Bersi area is made mainly of metamorphic rocks, intruded by plutonic rocks (Figure 2). Metamorphic rocks consist of three mains groups: the first group comprises mafic to ultramafic rocks (amphibolite, garnet amphibolite, garnet-chlorite amphibolite, hornblendite and metagabbro); the second group is made of orthogneisses (tonalitic orthogneiss, biotite orthogneiss and amphibolebiotite orthogneiss) and the third group consists of paragneisses (biotite-garnet gneiss, garnet-kyanite gneiss, biotite-sillimanite gneiss, and calc-silicate gneiss). Plutonic rocks belong to the large Adamawa-Yadé batholith $[9,19,35,42,43,48]$ and consist of tonalite, trondhjemite, granodiorite, biotite granite and leucogranite. These two major lithological groups are recovered in place by sediments and volcanic rocks. Structurally, the study area include two branches of the major shear zones: (a) the NESW Tcholliré-Banyo shear zone passing through Karna, Mbé and Ndong Benue and (b) the ENE-WSW Central Cameroon shear zone that cross Sassa-Bersi locality and Ngaoudéré scarp. Polyphase deformation $\left(D_{1}\right.$ to $\left.D_{4}\right)$ has been registered in the metamorphic rocks of the study area. Structural data have been reported on the geological and structural map of Figure 2. 


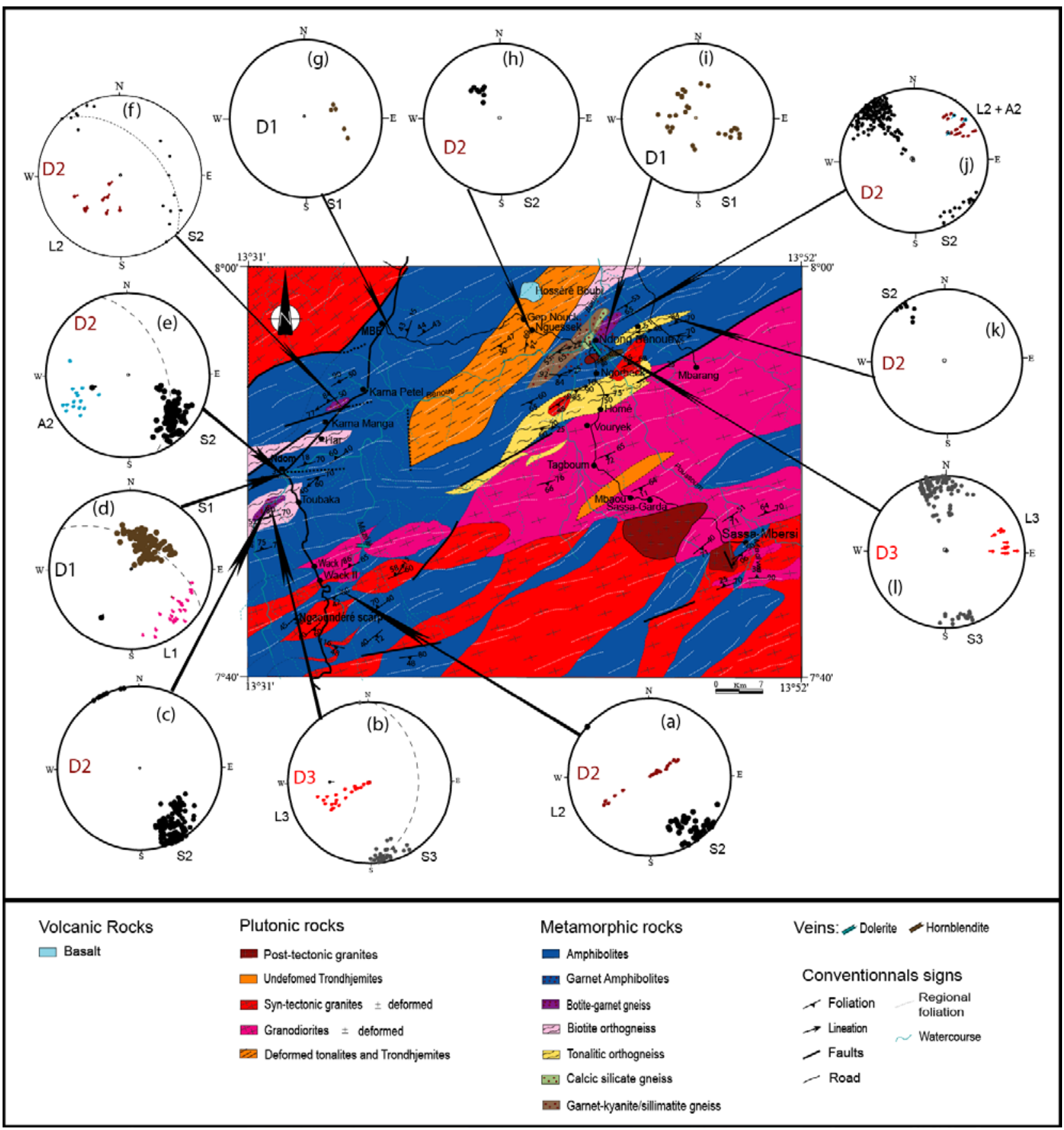

Figure 2. Geological and structural map of the Mbé - Sassa-Mbersi area whit the stereograms of the markers of $\mathrm{D}_{1}$ to $\mathrm{D}_{3}$ phase of deformation in some localities of this area.

\subsection{Petrography}

\subsubsection{Metamorphic Rocks}

\section{Amphibolite}

Amphibolite outcrop as slabs, blocks or as elongated enclaves in granites and orthogneisses. Amphibolites consist of amphibolite without garnet, garnet amphibolite and garnet-chlorite amphibolite. Amphibolite without garnet is massive, mylonitized or migmatitic, dark in colour and display granitic (pegmatitic or aplitic in composition) and quartz veins concordant or discordant to the foliation. In place, as at the localities of Karna (quarry) and Mbé, some outcrops show alternating quartzo-feldspathic and biotite-and amphibole-rich layers, associated with granitic material
(Figure 3a; Figure 4a, Figure 4b, Figure 4d) showing migmatitic appearance. These rocks display medium to coarse-grained structure. The texture can be granoblastic, granoporphyroblastic, granonematoblastic and mylonitic and consist mainly of amphibole - plagioclase - opaque minerals \pm pyroxene \pm garnet \pm rutile \pm oxides.

Garnet amphibolite crops out as metric to centimetric slabs at the Ndong Bénoué, Mayo Lou and Mayo Mbanna. The rock is dark and show medium to coarse-grained structure. It is characterized by granoblastic or granoprophyroblastic texture, made of amphibole, garnet (with variable size), plagioclase and biotite. Accessory minerals are oxides, titanite. Secondary minerals are made of quartz and biotite. 
Garnet-chlorite amphibolite crops out as blocks or as elongated and flattened enclaves concordant to the banding of orthoneisses of Ndong Bénoué. They show mylonitic texture constitute of globular blasts of garnet (whit inclusion of quartz and rutile), and some ovoid crystals of plagioclase moulded by a greenish matrix consisting essentially of fine crystals of chlorite. Opaque minerals and graphite are accessory. Epidote, calcite and sericite are the secondary minerals.

\section{Orthogneiss}

Orthogneiss outcrop as slabs or as metric to decametric blocks (at Ndong Bénoué, Lasséré, Toubaka, Ndom and wack localities), arranged in a parallel direction to the regional foliation. They appear also as enclaves in granites at the Ngaoundéré scarp where they are associated with amphibolite. Orthogneisses are grey dark or grey light in colour and show foliation characterized by alternating quartzo-feldpathic and ferromagnesian rich layers. It displays minerals with fine to medium size. Their exture are either granolepidoblastic or granonematoblastic either granoblastic heterogranular made mainly of quartz, feldspar, plagioclase, amphibole, biotite and oxides.
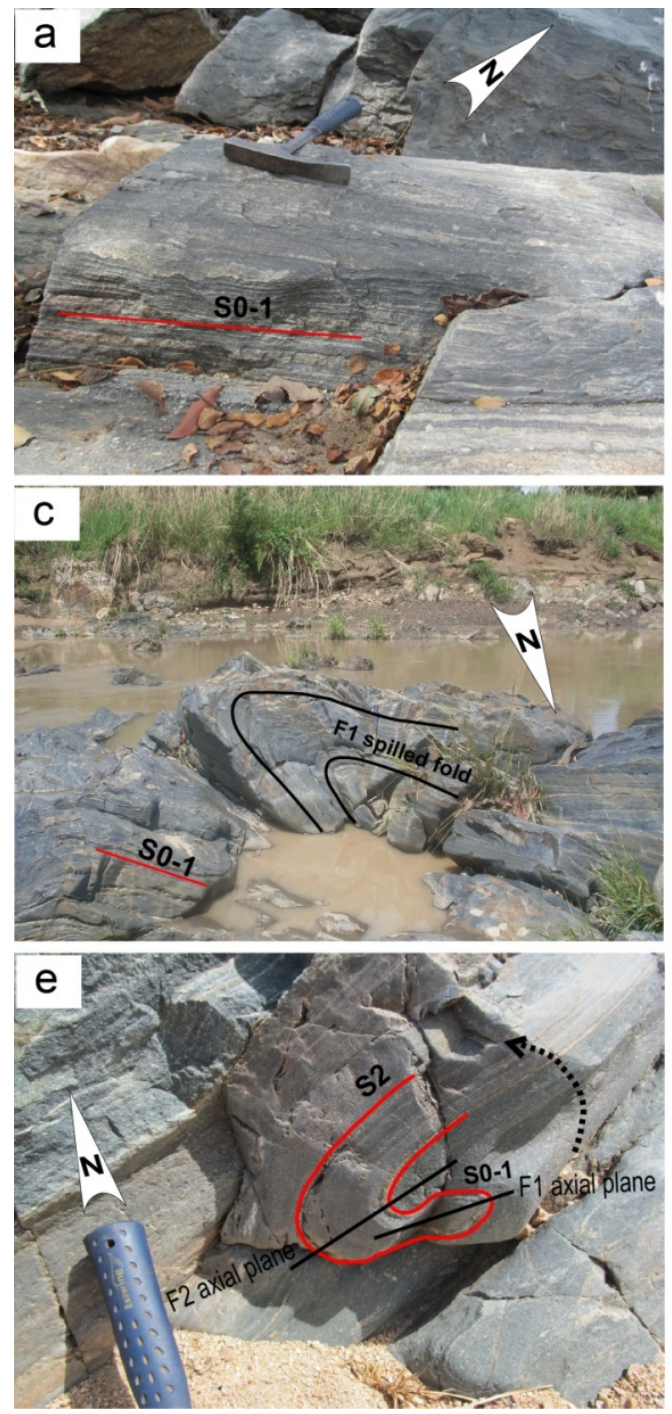

\section{Paragneisses}

Paragneisses are composed of biotite-garnet gneisses, garnet-kyanite gneisses, biotite-sillimanite gneisses and calc-silicate gneisses.

Biotite-garnet gneisses mainly crop out in the Benue river of the Ndong Bénoué (outcrop in strips) and Toubaka (outcrop in slabs) localities and in the Karna quarry (outcrop in beveled layers in the amphibolites). The rock is brown and the grains size is medium. Their texture are mylonitic, ultra-mylonitic or grano- lepidoblastic and mainly made of quartz + biotite + garnet + plagioclase.

The garnet-kyanite gneisses are found in contact with amphibolites in the Benue river of the locality of Ndong Bénoué. The rock, brown-light in colour show medium to coarse grains. Texture is mylonitic, grano- lepidoblastic or grono-lepidoclastic hetero-granular with composition of quartz + biotite + garnet + plagioclase \pm kyanite \pm sillimanite \pm feldspar \pm rutile.

Biotite-sillimanite gneisses appear as beveled layers in garnet-kyanite gneisses. The rock is grey and show fine grain minerals made of quartz + biotite + garnet + plagioclase \pm sillimanite \pm feldspar. Prehnite and muscovite are secondary. Texture is grano- lepidoblastic.
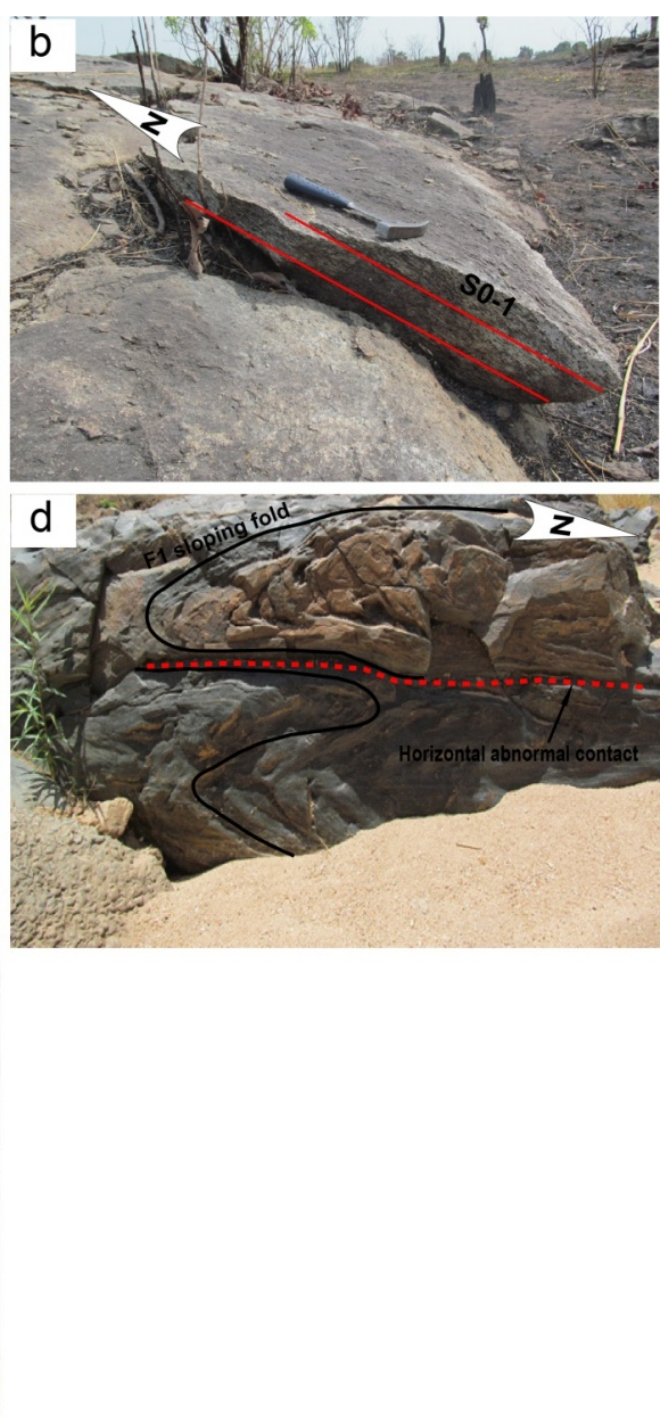

Figure 3. Structures of $\mathrm{D}_{1}$ phase of deformation at the Mbé - Sassa-Mbersi area. (a) horizontal $\mathrm{S}_{1}$ foliation at the Mayo Mbanna river around the Ndong Bénoué locality; (b) Sub-horizontal $\mathrm{S}_{1}$ schistosity in the tonalite of Nguesseck locality; (c) $\mathrm{F}_{1}$ fold weakly flowed toward ESE affecting the So-1 mylonitic surface in the Benue river at Ndom locality; (d) sloping fold with SSE vergence and abnormal contact at Ndom locality; (e) $F_{1}$ fold with subhorizontal axial plane transposed in $\mathrm{F}_{2}$ forming thus the $\mathrm{S}_{2}$; Benue river at Ndom locality. 

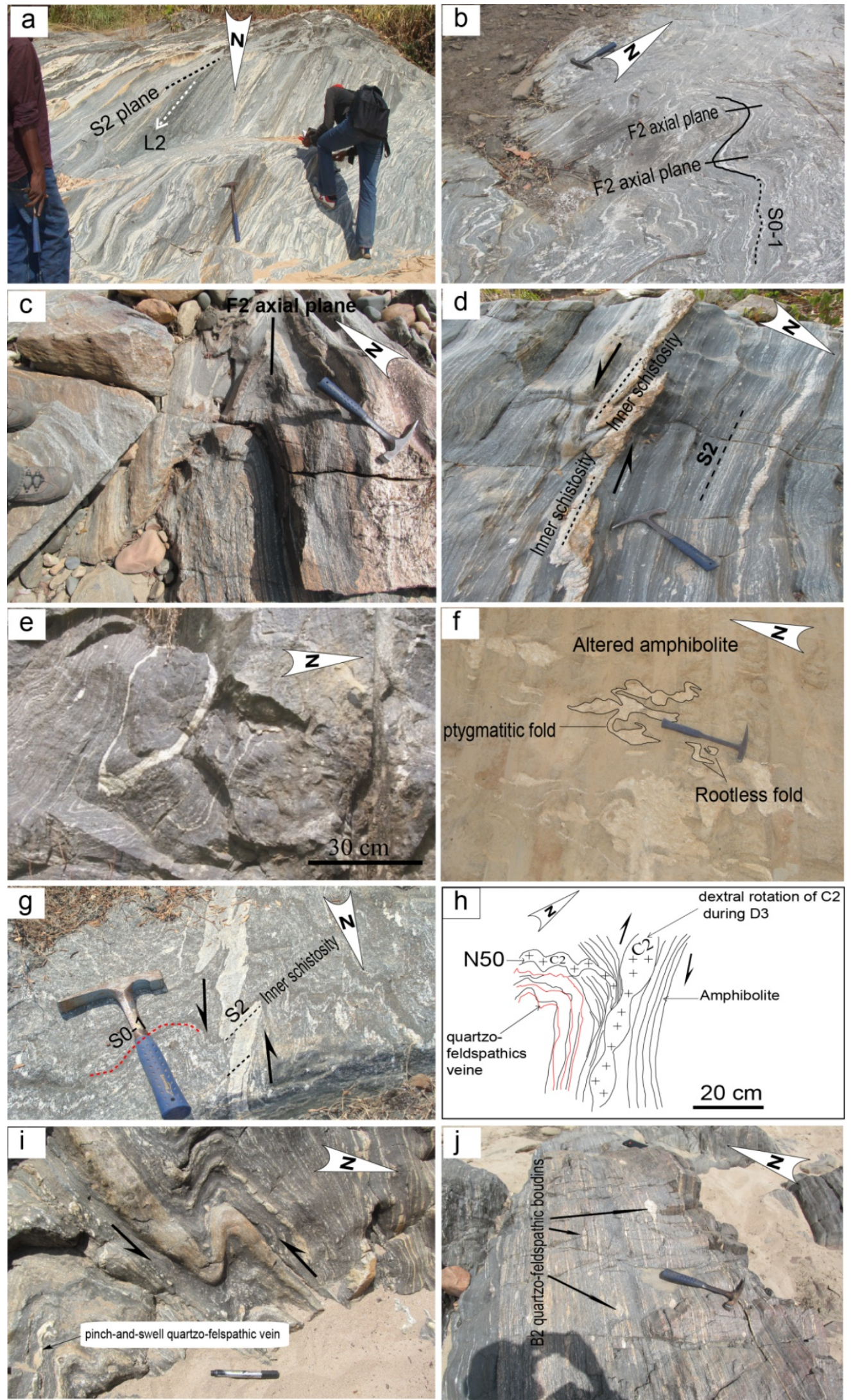

Figure 4. Structures of $D_{2}$ deformation phase at Mbé - Sasa-Mbersi area. (a) $S_{2}$ foliation carrying the mineral and stretching lineation marked by amphibole and plagioclase alignment (Ndom locality); (b) similar fold $\mathrm{F}_{2}$ in the amphibolites of Mbé. The hinges and flanks of these folds described the crenulation schistosity (AP = axial plane); (c) isopach fold in the Mayo Lou river around the Ndong Benoue locality; (d) pegmatite vein concordant to the $\mathrm{S}_{2}$ and folded in form of compressed « $\mathrm{S}$ » with sinistral movement and N50E orientation in the amphibolites of Mayo Lou; (e) dissymmetric sheath fold $F_{2}$ in the Karna carry; (f) discontinuous and folded pegmatite (ptygmatitic and rootless folds) in the altered amphibolites of the tourer trench of Ngaoundéré scarp; (g) sinistral syn-shearing quartzo-felspathic vein folded, podgy and moved the $\mathrm{S}_{0-1}$ foliation at the Karna carry; (h) perturbation zone: dextral rotation veins shearing $\mathrm{C}_{2}$ in $\mathrm{C}_{3}$ during the $\mathrm{D}_{3}$ at Ndong Benoue. These veins are in pinch-and-swell boudin form; (j) pinch-and-swell quartzofeldspathic vein in a $F_{2}$ fold in the amphibolites at Ndong Bénoué; (i) quartzo-feldspathic boudins with length tail of crystallisation in the amphibolites of Ndong Bénoué. 
Calc-silicate gneisses crop out in strips about two meters wide and more than 20 meters long between outcrops of garnet-kyanite gneisses. The rock is grey with medium size of grains. Their texture is granoblastic or gronoclastic. The mineralogical composition is clinopyroxene + dolomite + calcite + amphibole.

\subsubsection{Plutonic Rocks}

\section{Tonalite}

Tonalite crops out as slabs at the northern part of the study area, in the Nguesseck village (Figure 3b). Rock is light in colour, with medium-grained structure and display schistosity/foliation marked by preferred orientation of amphibole and quartz or by alternating quartz-feldspar and amphibole rich layers. Rock shows porphyritic texture, made of quartz, plagioclase, amphibole, biotite and Kfeldspar.

\section{Trondhjemite}

Trondhjemite crops out as slabs in the garnet amphibolite at the Benue river, or as vein in granodiorite respectively at Ndong Bénoué and Mbaou localities. This veins have approximately 20 meters long and are trended mostly N-S. Rock is light in colour and displays fine to coarse grained-structure with intra-crystalline deformation marked by elongated quartz, plagioclase and biotite crystals. These minerals are elongated secantly to the foliation of host amphibolite. Trondjemite consist mainly of plagioclase and quartz phenocrysts, embedded in groundmass made of biotite, plagioclase, quartz and sometime garnet.

\section{Granodiorite}

Granodiorite is more often associated with granite in heterogeneous outcrops. It also crops out as homogenous slabs or blocks to the East (Mbaou locality) and Northeast (Home and Ndong Bénoué localities) of the studied area. Rock is grey in colour with medium to coarse-grained structure. Some grains of feldspar show shape preferred orientation underlining the schistosity of the rock. The texture of granodiorite is granular porphyritic composed mainly of amphibole, quartz and feldspar phenocrysts, embedded in the finer grained matrix made of quartz, feldspars and biotite.

\section{Granite}

Granite is the most abundant plutonic rock of the southern part (Sassa-Mbersi, Wack and Ngaoundéré scarp) of the study area where it crops out as elongated massifs with high altitude. In the northern part (Mbé, Ndong Bénoué, Ndom, Toubaka), granite crops out commonly as veins and rarely as blocks in hosts amphibolite or orthogneiss. They can crop out often as minor massifs of low altitude (Djer massifs and Ndong Bénoué). The veins are either parallel or secant to the schistosity/foliation of the host rocks. Granites are grey to grey light in colour with fine to medium-grained structure. Their texture is granular porphyritic and made mainly of quartz - feldspars - biotite \pm pyroxene. Epidotes, calcite and chlorite are the most secondary minerals.

\subsection{Structural Data}

On the field, the sequence of structures is well preserved in metamorphic rocks. Meso-structural analysis work has permitted to identify three ductile deformation phases that we termed $D_{1}, D_{2}$ and $D_{3}$ according to the chronology of these structures. These three ductile deformations are affected by a latest and only brittle deformation phase name $\mathrm{D}_{4}$

\subsection{1. $D_{1}$ Deformation}

The first deformation phase is recorded in amphibolite and tonalite of Nguesseck, Ndong Bénoué and Ndom localities. This deformation phase is characterized by flat layering $S_{0-1}$ foliation/schistosity bearing $L_{1}$ lineation and the development of $F_{1}$ fold. $S_{0-1}$ is defined either by quartz-feldspar layers that alternate with ferromagnesian rich layers, or by the shaped orientation or elongation of quartz and feldspar crystals that underline intracrystal deformation (Figure 3). It is essentially subhorizontal or dipping shallowly (Figure 3a and Figure $3 b$ ) toward NE or SW at Ndom locality and toward NW or SE, in other localities. Its strike change from N-S to NW-SE and the majority of strikes being NNW-SSE (Figure 2d, Figure $2 \mathrm{~g}$ and Figure 2i). In the Ndom locality, western part of the study area, poles of foliation define a great circle pattern whose the best pole consistent with $\mathrm{L}_{2}$ lineations and $\mathrm{F}_{2}$ fold axes (Figure 2d). Although difficult to observe in the field, because of the effects of the $\mathrm{D}_{2}$ and $\mathrm{D}_{3}, \mathrm{~L}_{1}$ lineations, observed in some places, are commonly mineral lineations, defined by alignment of amphibole, or stretching lineations, formed by elongated feldspar and quartz. $\mathrm{L}_{1}$ plunges mainly to the SE or SSE with horizontale to subhorizontal angle ( 1 to $35^{\circ}$; Figure 2 ). During the $D_{1}$ deformation phase $\mathrm{S}_{0-1}$ is partially to totally transposed into $F_{1}$ folds. The $F_{1}$ folds developped during this deformation phase consist of asymetrical sloping folds with axial plan concordant to $\mathrm{S}_{0-1}$. These fold are recumbent further to an overlaping whose the surface is concordant to the axial plane of $\mathrm{F}_{1}$ (Figure $3 \mathrm{~d}$ ). $\mathrm{F}_{1}$ folds and $\mathrm{L}_{1}$ lineations axis plunge slighly toward SE. These firsts structurals elements are strongly partially or totally transposed during the second deformation phase.

\subsection{2. $\mathrm{D}_{2}$ Deformation}

During the second phase of deformation, the $\mathrm{S}_{0-1}$ is partially to totally changed into $S_{2}$ foliation/schistosity in amphibolite and orthogneisses. $S_{2}$ is marked either by alternating quartz-feldspathic rich and ferromagnesian rich layers or by preferred orientation of amphibole and biotite (in granodiorite and granite). The $\mathrm{S}_{2}$ planes trend mostly NE-SW to ENE-WSW with steep dip ranging between $40^{\circ}$ and $80^{\circ}$ toward NW or SE (Figure $4 \mathrm{a}$ ). These geometrical positions and dipostions are also showed in the stereonet plot of Figure 2a, c, e, f, h, j and k, where the poles of $S_{2}$ are grouped near the fundamental circle of the diagram but in the NW and SE quarters. However, in some outcrop, the dip of $S_{2}$ is lowest than $40^{\circ}$, which is attributed to the partial or incomplete transposition of $\mathrm{S}_{0-1}$ in these areas. The $S_{2}$ planes contain horizontal to subhorizontal $L_{2}$ lineations. $\mathrm{L}_{2}$ are defined by elongated and stretched feldspar, amphibole and biotite, in a parallel direction to the trend of $\mathrm{S}_{2}$ foliation/schistosity, with low plunging ranging between $5^{\circ}$ and $30^{\circ}$ toward NE or SW (Figure 2a, Figure 2e, Figure $2 \mathrm{f}$ and Figure 2j). The folds developed during this deformation phase are upright, rootless, training, asymmetric, ptygmatitic and sheath folds with axial plane parallel to the trend of $\mathrm{S}_{2}$ planes (Figure $4 \mathrm{~b}$, Figure 4c, Figure 4d, Figure 4e and Figure 4f). $\mathrm{F}_{2}$ folds 
axis and $\mathrm{L}_{2}$ lineation plunge with low angle toward NE or $\mathrm{SW}$. In place, the $\mathrm{S}_{0-1}$ planar structure display inflexion at the contact of $\mathrm{N} 50 \mathrm{E}$ or $\mathrm{N} 60 \mathrm{E} \mathrm{C}_{2}$ shear planes that are delineated by quartzo-feldspathic or granitic veins, with inner schistosity concordant to the $\mathrm{S}_{2}$ foliations (Figure 4g). NE-SW $\mathrm{C}_{2}$ shear planes cut $\mathrm{S}_{0 / 1}$ with sinistral motion. $\mathrm{B}_{2}$ Boudins developed during the $\mathrm{D}_{2}$ deformation consist of intrafolial granitic veins, pinched and swelled in a parallel direction to the $S_{2}$ structure and underlining the regional stretched direction (Figure $4 \mathrm{i}$, Figure $4 \mathrm{j}$ ). These Boudins are complete or incomplete but, the complete one are more expressed in the study areas. The incomplete boudins are localised at the limbs and hinges of the $F_{2}$ asymmetric and rootless folds.
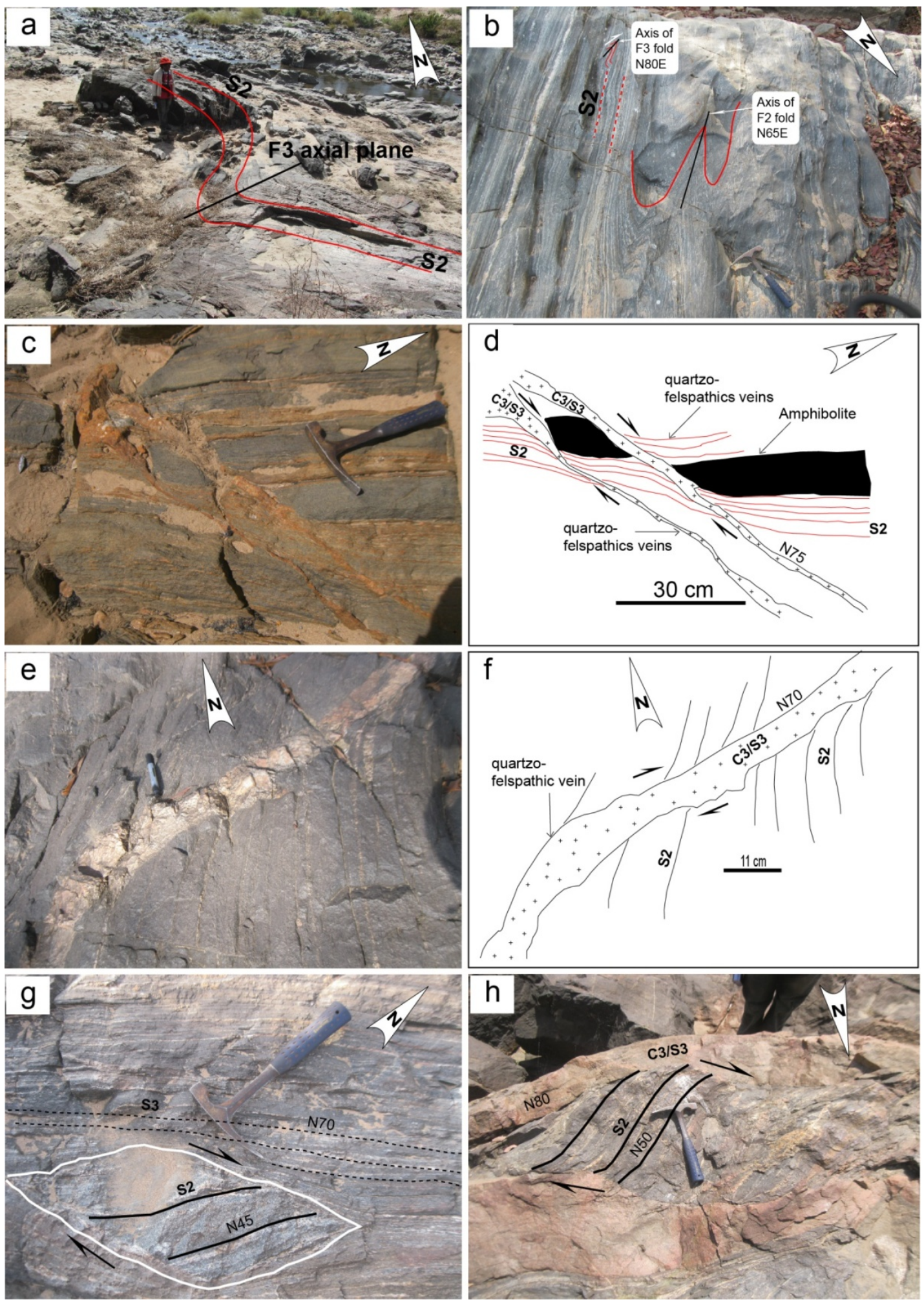

Figure 5. Illustration of $D_{3}$ structures of the Mbé - Sassa - Mbersi area. (a) $F_{3}$ fold at Ndong Bénoué with sub-vertical axial plane and flanks; (b) $F_{3}$ fold with « $\mathrm{Z}$ » morphology and dextral movement on the flank of a $F_{2}$ fold in the amphibole biotite orthogneiss at Mayo Lou; (c) (d) (e) and (f) present the C3 shearing at Ndong Bénoué. (d) and (f) are respectively the schematic representation of (c) and (e); (g) amphibolite boudin with internal foliation N45-directed corresponding to the $S_{2}$ in the amphibolite with $S_{3}$ foliation; (h) amphibolite boudin with internal N50-directed foliation taken in a aplite dextral shearing vein directed N80E. 


\subsection{3. $\mathrm{D}_{3}$ Deformation}

The structural elements developed during this deformation phase are the consequence of the tectonic transposition of the previews structures. $D_{3}$ is characterized by $S_{3}$ schistosity, concordant to the axial plan of $\mathrm{F}_{3}$ folds and underlined by shaped preferred orientation of amphibole and biotite. In place, $\mathrm{S}_{3}$ schistosity is reinforced by deformed aplitic or pegmatitic veins, oblique to the $S_{2}$ planes. $S_{3}$ is mostly trended between N70E, N75E or E-N80E, with steep dip (ranging between $60^{\circ}$ and $90^{\circ}$ ) toward SSE or NNW. The stereonet plot of Figure $2 \mathrm{~b}$ and $\mathrm{l}$ show that $\mathrm{S}_{3}$ pole cluster in the SSE and NNW quarters of the diagram, but near the fundamental circle; suggesting the steep dipping of $\mathrm{S}_{3}$ such as observed and measured on the field. $\mathrm{L}_{3}$ lineation contained on the $\mathrm{S}_{3}$ planes is marked by stretched feldspar and amphibole. $\mathrm{L}_{3}$ plunges with low angle (ranging between $20^{\circ}$ and $40^{\circ}$ ) toward E or ENE (at Ndong Bénoué area and surroundings), and WSW at Ndom and Toubaka areas (Figure $2 \mathrm{~b}$ and Figure 2l). However, in the northern side of the Karna quarry, $\mathrm{L}_{3}$ is marked by dextral striations plunge with high angle $\left(40^{\circ}\right.$ to $\left.70^{\circ}\right)$ towards $\mathrm{SW}$. The $\mathrm{F}_{3}$ folds developed during this deformation phase are mesoscopic and result from the folding of the $S_{2}$ planes or from refolding of the $F_{2}$ axial planes. Based on the dip angle of their axial plane the $F_{3}$ folds consist mainly of upright folds (Figure 5a); and their axis is trended N80E in amphibole-biotite orthogneisses of Mayo Lou (Figure 5b). The $\mathrm{C}_{3}$ shear planes are concordant to $\mathrm{S}_{3}$ foliation and the axial plane of $F_{3}$ folds. They transpose the NE-SW $D_{2}$ planar structures and are outlined by granitic veins (Figure 5 a, b, c, d, e, f). $C_{3}$ trend mostly N70E to N80E in a parallel direction of the Central Cameroon shear zone and show dextral shear motion (Figure 5c, d, e, f). $B_{3}$ boudins consist of elongated amphibolite enclaves in orthogneisses, slightly transposed (Figure 5g, h). These boudins have an internal foliation materialized by the ribbon of the rock and directed N50 to N55E (concordant to the trend of $\mathrm{S}_{2}$ foliation). This inner foliation is discordant to the outer $S_{3}$ foliation rather trended N70E or N80E.

\subsection{4. $\mathrm{D}_{4}$ Deformation}

The $\mathrm{D}_{4}$ deformation phase is characterized by fractures, faults and tension gashes that are all subsequent to the structural elements of the previews deformation phases (Figure 6). These structures are observed on all the lithological groups. Fractures are generally dry and are trended N120E to N130E. Faults consist of the $\mathrm{C}_{4}$ shear planes that are generally filled or not with no deformed granitic and quartz veins. These $\mathrm{C}_{4}$ shear planes show dextral or sinistral movement (Figures 6c and d). Tension gashes are constituted of small veins of quartz or calcite (Figure $6 \mathrm{c}$ ).
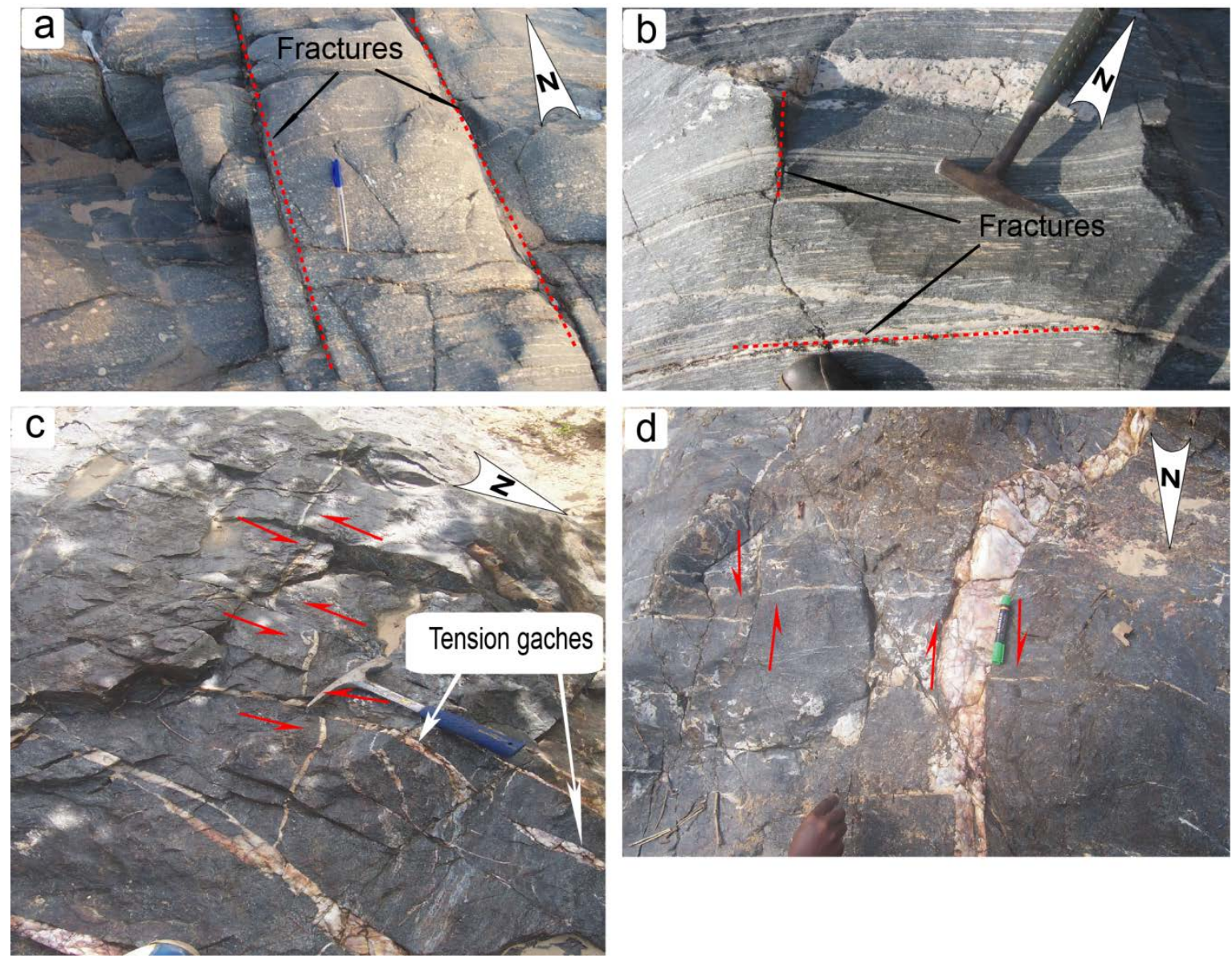

Figure 6. Photography illustrating the $\mathrm{D}_{4}$ structures elements in the Mbé - Sassa-Mbersi area. (a) and (b) fractures discordant and/or concordant to the foliation in the amphibolites of Ndong Bénoué; (c) fissures filled in by quartz veins, and fault system in step materialized by quartz veins moved by fracture plane in sinistral movement in the amphibolite of Toubaka locality; (d) conjugate fault characterized by the gap of a quartzo-feldspathic veins parallel to the schistosity of amphibolites, respectively in sinistral movement by fracture plane and in dextral movement by a quartz vein (Toubaka). 


\section{Discussion}

\subsection{Tectono-magmatic evolution of the Mbé - Sassa-Bersi area}

The first phase of deformation $\left(\mathrm{D}_{1}\right)$, mainly recorded in amphibolite and tonalite is illustrated by a shallowdipping foliation $S_{0 / 1}$ with $F_{1}$ folded profile. The planar structures bear both mineral and stretching lineation $\mathrm{L}_{1}$. $\mathrm{S}_{0 / 1}$ planes shows variable direction, from NW-SE to NNW-SSE or rarely N-S and are generally inclined toward SW or NE. This direction is different to the one described by [17] in the Tcholliré region, to the NE of Mbé - Sassa-Bersi area where $\mathrm{S}_{0 / 1}$ trend between $\mathrm{E}-\mathrm{W}$ and $\mathrm{N}-\mathrm{S}$. The change suggests probable reorientation of $\mathrm{S}_{0 / 1}$ structure during $\mathrm{D}_{1}$ deformation phase. The opposite dip of $\mathrm{S}_{0 / 1}$ is probably due to the transposition by folding during the second deformation phase. $\mathrm{L}_{1}$ lineation and $\mathrm{F}_{1}$ fold axis are mainly trended parallel to the direction of $\mathrm{S}_{0 / 1}$ and plunge with low angle toward SSE or SE, suggesting transport of material from NW or NNW toward SE or SSE. $\mathrm{S}_{0-1}$ is flat and bears subhorizontal stretching and mineral lineation $\mathrm{L}_{1}$; in addition, $\mathrm{F}_{1}$ folds developed during the first deformation phase are mainly slopped (with horizontal axial plane). These structures and their geometrical arrangements suggest nappe structures already identified in the Mbé mylonitic group [21] considerate as evolved in probable early Pan-African crustal thrusting [14,25]. According to [5] and [49], the first deformation phase is attributed to the early Pan-African tectonic emplacement of nappes, verging toward the east. The NW or NNW dipping of the $F_{1}$ folds axial plane suggests $\mathrm{SE}$ or SSE verging for the tectonic nappe in the study area. The $\mathrm{D}_{1}$ deformation is recorded to amphibolite that show banding marked by quartzofeldspathic-rich layers (of granitic composition) alternating with ferromagnesian-rich layers, suggesting their migmatitic character (Figure 3a, Figure 3c, Figure $3 \mathrm{e}$ and Figure 4b, Figure 4g). This character indicates an early partial melting and emplacement of granitic material during $\mathrm{D}_{1}$ deformation phase as suggested by [9] concerning the interpretation of the tectono-magmatic and metamorphic evolution of the Central African Orogenic Belth in Cameroon. Thus the presence of the $S_{0 / 1}$ schistosity in the tonalite suggests that this plutonic rock was emplaced before or during the $D_{1}$ deformation phase in this area.

The structural elements characterising the second phase of deformation $\mathrm{D}_{2}$ result from the tectonic transposition of $S_{0 / 1}$ foliation planes and $F_{1}$ folds. $D_{2}$ is characterized by the development of multiplicity of structures among which (1) NE-SW to ENE-WSW foliation $S_{2}$ with steep dip toward NW or SE bearing (2) subhorizontal $\mathrm{L}_{2}$ lineation; (3) $F_{2}$ folds of different shape with axial plane in a parallel direction to $S_{2}$ and axis parallel to $L_{2}$; (4) $B_{2}$ boudins and (5) $C_{2}$ shear planes. Asymmetric $F_{2}$ folds and $B_{2}$ boudins are developed in the orthogneisses. According to [50,51] these types of boudins and folds are typical of shear zones. The position and disposition of $S_{2}$ and $L_{2}$ is similar to the one identified along the Tcholliré-Banyo shear zone [17]. The presence of asymmetric and similar folds $\left(\mathrm{F}_{2}\right)$ and asymmetric boudins $\left(\mathrm{B}_{2}\right)$, folds suggest that the dominant mechanism of deformation is simple shear. According to
[52], the parallelism between $L_{2}$ and $F_{2}$ fold axis suggests that simple shear produced the folding. However, upright folds and the relative symmetry of some boudins indicate a significative implication of NW-SE shortening. The spatial association of shear and shortening shows that transpression has acted in the study area, along the TBSZ. $\mathrm{L}_{2}$ lineation and $\mathrm{F}_{2}$ folds axis plunge with low angle toward NE or SW. In addition, stretching and mineral lineation $L_{2}$ are trended in a parallel direction to the $S_{2}$ foliation. The geometrical arrangement of both structures $\left(L_{2}\right.$ and $\left.S_{2}\right)$ is frequent in transcurrent shear zones [19] and in transpressional shear zones characterized by simple shear dominated transpression [53]. The transpressive character of $\mathrm{D}_{2}$ deformation has been also showed in the Kimbi area in the western part of the Central Cameroon domain and in West Tibati along the Central Cameroon shear zone [1,52]. However, this character of $D_{2}$ is different to the results obtained in eastern Cameroon, where $\mathrm{D}_{2}$ deformation is characterized by convergence with crustal shortening $[4,13]$. On the basis of data presented in this study, we can suggest that the dominant tectonic regime during $\mathrm{D}_{2}$ deformation phase in Mbé Sassa-Mbersi area is simple shear dominated transpression. The subhorizontal and low plunges $\left(\leq 30^{\circ}\right)$ of $\mathrm{L}_{2}$ lineations (Figure 2a, e, f and j) on NE-SW subvertical planar structures suggest oblique displacement of blocks along the Tcholliré - Banyo shear zone. Field observations show that boudinaged granitic veins (aplite, pegmatite) are concordant to the $\mathrm{C}_{2} / \mathrm{S}_{2}$ planes of metamorphic rocks (Figure $4 \mathrm{~h}$ and $\mathrm{j}$ ). These veins are deformed and display intern shistosity concordant to the $\mathrm{S}_{2} / \mathrm{C}_{2}$ foliation/shear planes of metamorphic rocks and suggest their emplacement contemporaneous to shearing (Figure 4d). According to [17,55,56], link between granite and shear zones leds to the view that major crustal shear zones play an important role in extraction and emplacement of magmas through the crust. The $D_{3}$ deformation phase result from the tectonic superposition of previous structural elements. The main structural elements that determine this deformation phase are $F_{3}$ folds that result from the transposition or from refolding of $F_{2}$ folds; subvertical $S_{3}$ foliation trended N70-75E to N80E developed at the axial plane of $F_{3}$ folds; subhorizontal stretching and mineral $\mathrm{L}_{3}$ lineation; and $\mathrm{C}_{3}$ shearing trended in a parallel direction to $\mathrm{S}_{3}$ foliation. These structural elements transpose generally those developed during previous deformation phase $\mathrm{D}_{2} . \mathrm{S}_{3}$ show steep dipping and bear stretched and/or mineral lineation that plunge with low angle characterizing dominantly transcurrent nature of $\mathrm{D}_{3}$ deformation. The direction of $\mathrm{S}_{3}$ and $\mathrm{L}_{3}$ is similar to the one identified along the Central Cameroon shear zone in West Tibati and Koata areas $[3,18,19,57]$. The geometrical position and disposition of $\mathrm{S}_{3}$ and $\mathrm{L}_{3}$ suggest transpression according to $[10,58,59]$ or simple shear dominated transpression [53]. However, in place, $\mathrm{L}_{3}$ are subvertical and plunge with high angle $\left(40^{\circ}\right.$ to $70^{\circ}$ ). According to [53], subvertical foliation associated to subvertical lineation is characteristic of pure shear dominated transpression. The coexistence of simple shear and pure shear can be explained by strain partitioning in the study area produced by transpression. According to $[60,61,62]$, the consequence of transpression is the partitioning of strain into domains that are predominantly 
transcurrent associated with domains that are predominantly compressive. According to [63,64,65] Indeed, the trends of $\mathrm{L}_{3}$ lineations tend to rotate from ENE-WSW to E-W. strain partitioning in inclined or oblique transpressional settings is materialized by the rotation of lineation. On the field, the trends of $\mathrm{L}_{3}$ lineations tend to rotate from ENE-WSW to E-W suggesting strain partitioning induced by transpression. We suggest that a dominant pure shear component may have affected the Karna quarry while Ndong Bénoué, Ndom and Toubaka were affected by a dominant simple shear component along the ENE-WSW to E-W shear zone. The transpressive character of $\mathrm{D}_{3}$ is different to the one proposed by [1] in Central Cameroon but similar to the standpoint of [52] in Kimbi area and of [54] in Garga Sarali region (East Cameroon). Most of the ENE-WSW to E-W S $\mathrm{S}_{3} / \mathrm{C}_{3}$ shear planes are filled by boudinaged and foliated granitic veins suggesting magma emplacement during $\mathrm{D}_{3}$ deformation phase, under the control of the $\mathrm{C}_{3}$ shear plan that correspond to the Central Cameroon shear zone. The conformability between this shear zone and granite magmatism have been already showed by $[1,19,66]$. The presence of deformed granitic veins in the N75E to N80E $\mathrm{S}_{3} / \mathrm{C}_{3}$ planes suggest development of granite magmatim during $\mathrm{D}_{3}$ deformation phase under the control of crustal structure which must be correspond to the Central Cameroon shear zone.

The fourth deformation phase $\mathrm{D}_{4}$ is marked by faults, tension gashes and fractures. These structural elements suggest brittle character of this deformation phase. Faults are generally combined and show both dextral and sinistral shear motion trended. These faults and fractures display NW-SE. This direction was mentioned in the Tombel and Kimbi basement of the Pan-African fold belt and has been interpreted as traces of the Benue trough $[53,67]$.

\subsection{Tectonic and kinematic evolution of the Tcholliré-Banyo and Central Cameroun Shear Zones}

It is proposed above that the Mbé - Sassa-Mbersi area is characterized by four deformation phase. The second and third tectonic phase are marked by the development of steeply dipping foliation planes bearing subhorizontal lineation both parallels to the general strike of the well know shear zones in CAOB. The NE-SW or ENE-WSW foliation/shearing is trended in a parrallel direction to the Tcholliré-Banyo shear zone. On the other hand, the N70EN80E foliation/shearing is concordant to the strike of Central Cameroon shear zone.
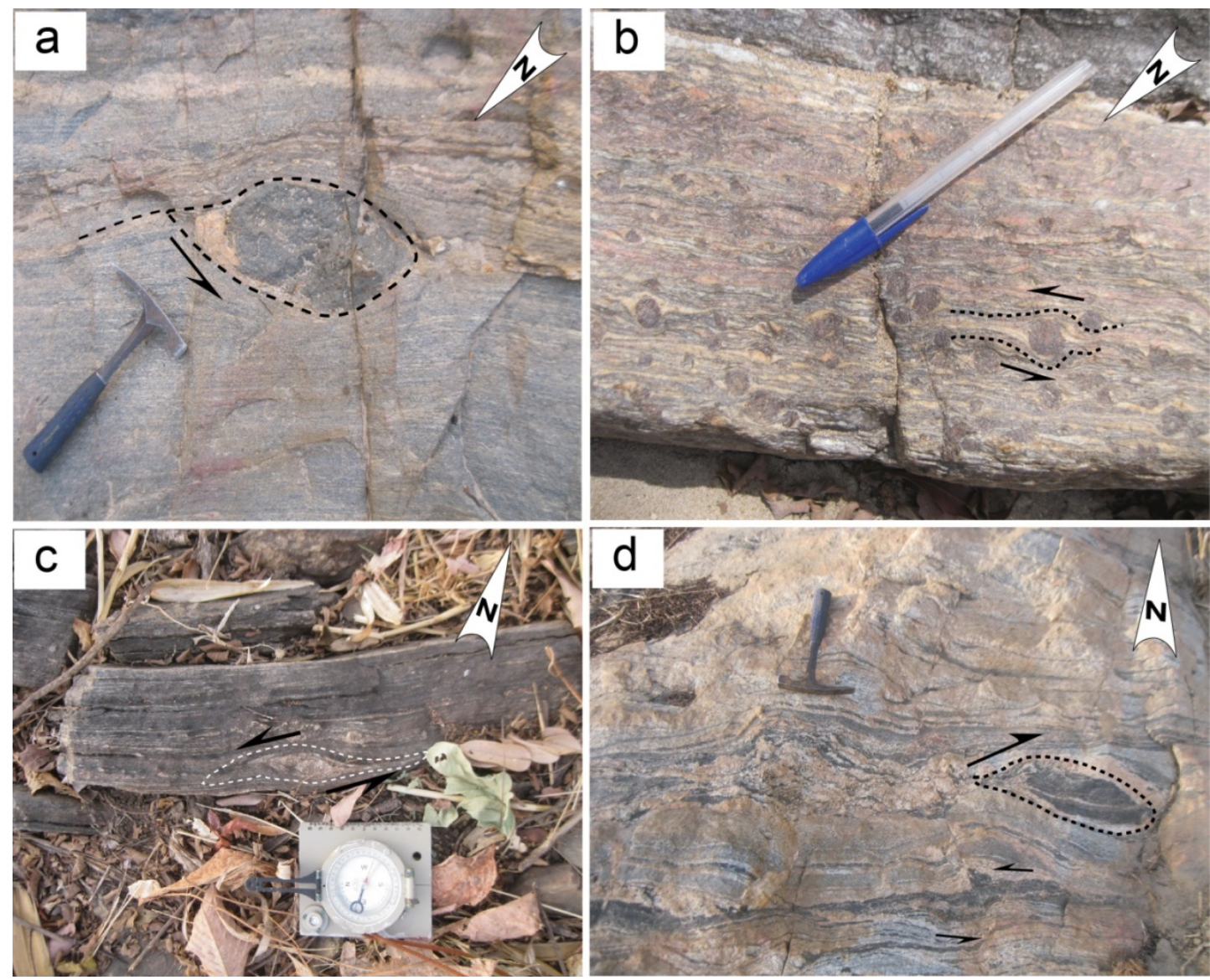

Figure 7. Cinematic markers at Mbé - Sassa-Mbersi area. (a) sinistral motion of amphibolitic boudin in orthogneiss at Ndong Bénoué locality; (b) sinistral rotation of garnet in garnet-kyanite gneiss of Benue river at Ndong Bénoué locality (c) asymmetrical structure in orthogneiss at Ndong Bénoué locality; (d) dextral rotation of amphibolite boudin in orthogneiss previously showing sinistral criteria in orthogneiss at Mayo Mbanna river around Ndong Bénoué locality. 
Structural data denote that the NE-SW shear zone evolve during the development of $\mathrm{D}_{2}$ deformation phase. However, according to [14] the Tcholliré-Banyo shear zone occurs between $\mathrm{D}_{2}-\mathrm{D}_{3}$ deformation stages. In this study, data shows progressive change of $\mathrm{S}_{0 / 1}$ at the contact of $\mathrm{S}_{2} / \mathrm{C}_{2}$ foliation/shear planes trended in the parallel direction to the TBSZ suggesting $\mathrm{D}_{2}$ evolution stage for this shear zone. The stage of evolution proposed in this study for the NE-SW or ENE-WSW shear zone is similar to the one recently suggested in granites and host schists (Rey-Bouba greenstone Belt) in the Tcholliré area [17] and in gneisses of the Mbé quarry [16] in our study area. The kinematic indicators such as (1) $F_{2}$ asymmetric and intrafolial folds consisting of boudinaged granitic veins emplaced during simple shear deformation; (2) clasts or boudins of amphibolite, feldspar and garnet with sigma $(\sigma)$ and asymmetric shape suggest sinistral shear movement along the TBSZ during $\mathrm{D}_{2}$ deformation phase (Figure $7 \mathrm{a}$, Figure $7 \mathrm{~b}$ and Figure $7 \mathrm{c}$ ). This sinistral kinematic is identical to the one proposed by [17] identified along the same shear zone in the Tcholliré area and to the one previously proposed by [9]. However, this kinematic is different to the one proposed by [16] in our study area. These authors suggest dextral shear movement along the TBSZ at the level of Mbé quarry. These results suggest that the Tcholliré-Banyo shear zone should have a complex kinematic evolution.

The N70E-N80E shear zone cut or transpose the NE-SW/ ENE-WSW former structures $\left(S_{2}\right.$ foliation, $C_{2}$ shearing and $B_{2}$ boudins) developed during $D_{2}$ deformation. The shear zone is outlined either by N75E boudinaged and foliated granitic veins or by N70E subvertical foliation (marked by quartzo-feldspathic rich layers alternating with ferromagnesian rich layers) that turn up the NE-SW $\mathrm{S}_{2}$ foliation in amphibolite boudins (Figures 5c-f; and 5g-h). This arrangement of structures suggests that the N70E-N80E shear zone is younger than the NE-SW/ ENE-WSW structures and belong to the $\mathrm{D}_{3}$ deformation phase in our study area. Kinematic indicators such as hooks (curvature of NE-SW foliation at the contact of N75E or N70E foliation) or inflexion of the internal foliation of amphibolite enclave at the contact with external foliation of orthogneiss (Figure 5e-f and 5g) and asymmetric amphibolite boudins (Figure 5g) suggest dextral shear motion. These results agree with the one of [1] that indicate later dextral shear movement (phase $\mathrm{D}_{3}$ ) along the CCSZ during the Pan-African orogeny. However, the same author propose an early sinistral shear movement $\left(D_{2}\right.$ phase) along the same Central Cameroon shear zone before the $\mathrm{D}_{3}$ one in the West Tibati area. Field structural data investigated in our study area show early sinistral shear movement $\left(D_{2}\right)$ rather along the NE-SW Tcholliré-Banyo shear zone as also suggested by the works of [17] in the Tcholliré area while the dextral shear movement is later and recorded to the CCSZ (Figure 5c-h).

\section{Conclusion}

Based on the, field petrographic and structural studies, we can conclude that:

(1) Four deformation phases $D_{1}, D_{2}, D_{3}$ and $D_{4}$ can be distinguished in the Mbé - Sassa-Bersi area.
(2) The first deformation phase $\left(D_{1}\right)$ is characterized by flat layering foliations $\mathrm{S}_{0-1}$ bearing subhorizontal stretching and/or mineral lineations $L_{1}$, recumbent isopach folds $F_{1}$; and overlapping. These structural elements are characteristic of the tectonic nappe verging SSE.

(3) The second deformation phase $\left(D_{2}\right)$ show diversity of ductile and linear structures. Geometrical characteristics of these structures suggest simple shear dominated transpressive deformation characterizing tranpressional shear zones. The dominant shear zone developed during this deformation is the NE-SW- ENE-WSW Tcholliré-Banyo shear zone. Kinematic markers show sinistral movement along of this shear zone during the Pan-African Orogeny. This tectonic phase is also charactyerized by emplacement of granitic magmatism under the control of above shear zone.

(4) The third phase $\left(D_{3}\right)$ is characterized by both simple shear and pure shear dominated transpressive deformation induced by strain partitioning. This deformation is associated to the development of the N75E-N80E Central Cameroon shear zone characterized by a dextral shear motion. As the Tcholliré-Banyo shear zone, this shear zone is also associated to the evolution and emplacement of granitic magmatism during the Panafrican Orogeny.

(5) The fourth deformation phase $\left(D_{4}\right)$ is brittle and responsible to the development of fractures trended generally NW-SE.

\section{Acknowledgments}

This manuscript is a part of the Ph.D of the first author. The authors thank the AUA (Association des Universités Africaines) and the AUF (Agence Universitaire de la Francophonie), for scholarships which has allowed to collect the field data.

\section{References}

[1] Ngako, V., Affaton, P., Nnange, J.M., Njanko, Th., 2003. PanAfrican tectonic evolution in central and southern Cameroun: transpression and transtension during sinistral shear movements. Journal of African Earth Sciences 36, 207-214.

[2] Penaye, J., Kröner, A., Toteu, S.F., Van Schmus, W.R., Doumnang, J.C., 2006. Evolution of the Mayo Kebbi region as revealed by zircon dating: an early (ca. $740 \mathrm{Ma}$ ) Pan-African magmatic arc in southwestern Chad. Journal of African Earth Sciences 44, 530-542.

[3] Njonfang, E., Ngako, V., Moreau, C., Affaton, P., Diot, H., 2008. Restraining bends in high temperature shear zone: the "Central Cameroon Shear Zone”, Central Africa. Journal of African Earth Sciences 52, 9-20.

[4] Nsifa, E., Tchameni, R., Nedelec, A., Siqueira, R., Pouclet, A., Bascou, J., 2013. Structure and petrology of Pan-African nepheline syenites from the South West Cameroon; Implications for their emplacement mode, petrogenesis and geodynamic significance. Journal of African Earth Sciences 87, 44-58.

[5] Ngako, V., Jegouzo, P., Nzenti, J.P., 1992. Champ de raccourcissement et de cratonisation du Nord Cameroun du Protérozoïque Supérieur au Protérozoïque Moyen. Comptes Rendu Académie des Sciences. Paris 315, 371-377.

[6] Nzenti, J.P., Barbey, P., Macaudière, J., Soba, D., 1988. Origin and evolution of the late Precambrian high-grade Yaoundé gneisses (Cameroon). Précambrian Research 38, 91-109.

[7] Castaing, C., Feybesse, J.-L., Thiéblemont, D., Triboulet, C., Chèvremont, P., 1994. Paleogeographical reconstructions of the Pan-African/Brasiliano orogen: closure of an oceanic domain or intracontinental convergence between major blocks. Precambrian Research 69, 327-344. 
[8] Trompette, R., 1997. Neoproterozoic (600 Ma) aggregation of Western Gondwana: a tentative scenario. Precambrian Research 82, 101-112.

[9] Toteu, S.F., Penaye, J., Poudjom Djomani, Y., 2004. Geodynamic evolution of the Pan-African belt in Central Africa with special reference to Cameroon. Canadian Journal Earth Sciences 41, 73-85.

[10] Ngako, V., Affaton, P., Djonfang, E., 2008. Pan-African tectonics in northwestern Cameroon: Implication for the history of western Gondwana. Gondwana research 14, 509-22.

[11] Van Schmus, W.R., Oliveira, E.P., da Silva Filho, A.F., Toteu, S.F., Penaye, J., Guimarães, I.P., 2008. Proterozoic links between the Borborema Province, NE Brazil, and the Central African Fold Belt. Geological Society, London, special Publication 294, 69-99.

[12] Dumont, J.F., 1986. Identification par télédétection de l'accident de la Sanaga (Cameroun): sa position dans le contexte des grands accidents d'Afrique Centrale et de la limite nord du craton congolais. Géodynamique 1, 13-19.

[13] Kankeu, B., Greiling, R.O., Nzenti, J.P., Runge, J., Bassahak, J., Hell, J.V., 2008. Pan- African tectonic evolution along the Adamoua shear zone, central Cameroon: The southern MbereDjerem high strain zone. 22nd Colloquim on African Geology, Hammanet-Tunisia, 4-6 November 2008: 69-71.

[14] Pinna, P., Calvez, J.Y., Abessolo, A., Angel, J.M., MekoulouMekoulou, T., Mananga, G., Vernhet, Y., 1994. Neoproterozoic events in the Tcholliré area: Pan-African crustal growth and geodynamics in central-northern Cameroon (Adamawa and North Provinces). Journal of African Earth Sciences 18, 347-353.

[15] Ngako, V., Jegouzo, P., Nzenti, J.P., 1991. Le Cisaillement Centre Camerounais. Rôle structural et géodynamique dans l'orogenèse panafricaine. Compte Rendu de l'Académie des Sciences, Paris 315, 457-463.

[16] Ngako, V. Njonfang, E., 2011. Plates amalgamation and plate destruction, the Western Gondwana history. In: Closson D (ed) Tectonics, InTech, pp 1-36.

[17] Nomo Negue, E., Tchameni, R., Vanderhaeghe, O., Sun, F., Barbey, P., Tekoum, L., Fosso Tchunte, P.M., Eglinger A., Saha Fouotsa, A.N., 2017. Structure and LA-ICP-MS zircon U-Pb dating of syntectonic plutons emplaced in the Pan-African BanyoTcholliré shear zone (central north Cameroon). Journal of African Earth Sciences 131, 251-271.

[18] Nzenti, J.P., Kapajika, B., Wörner, G., Lubala, R.T., 2006. Synkinematic emplacement of granitoids in a Pan-African shear zone in Central Cameroon. Journal of African Earth Sciences 45, 74-86.

[19] Njanko, T., Nédélec, A., Affaton, P., 2006. Synkinematic high-K calc-alkaline plutons associated with the Pan-African Central Cameroun Shear Zone (W-Tibati area): petrology and geodynamic significance. Journal of African Earth Sciences 44, 494-510.

[20] Dumont, J.F., Toteu, S.F., Penaye, J., 1985. Ensembles structuraux et principales phases de déformations panafricaines dans la zone mobile du Nord Cameroun, région de Poli. Revue des Sciences et Techniques, Série Sciences de la Terre, Yaoundé, 1, 9-23.

[21] Ngako, V., 1986. Evolution métamorphique et structurale de la bordure sud-ouest de la « série de Poli » (segment camerounais de la chaîne panafricaine). Mémoires et documents du Centre Armoricain d'Etude Structurale des socles, Rénnes 5, 185p.

[22] Njonfang, E., Moreau, C., Tchoua, F.M., 1998. La bande mylonitique Foumban-Bankim, Ouest Cameroun. Une zone de cisaillement de haute température. Compte Rendu Académie des Sciences de Paris 327, 735-741.

[23] Ganwa, A.A., 2005. Les granitoïdes de Méiganga: étude pétrographique, géochimique, structurale et géochronologique. Leur place dans la chaîne panafricaine. Thèse de Doctorat d'État (unpubl.), Université de Yaoundé I, 162 pp.

[24] Njonfang, E., Ngako, V., Kwékam, M., Affaton, P., 2006. Les orthogneiss calco-alcalins de Foumban-Bankim: témoins d'une zone interne de marge active panafricaine en cisaillement. Compte Rendu Geosciences 338, 606-616.

[25] Penaye, J., Toteu, S.F., Michard, A., Bertrand, J.M., Dautel, D., 1989. Reliques granulitiques d'âge Protérozoïque inférieur dans la zone mobile Panafricaine d'Afrique Centrale au Cameroun. Géochronologie U-Pb sur zircons. Compte Rendu de l'Académie des Sciences, Paris 309, 315-318.

[26] Louis, P., 1970. Contribution géophysique à la connaissance du bassin du Lac Tchad. ORSTOM, Paris, France, Mémoire 42, 308p.
[27] Braitenberg, C., Mariani, P., Ebbing, J., Sprlak, P.M.M., 2011. The enigmatic Chad lineament revisited with global gravity and gravity-gradient fields. Geological Society, London Spec. Publ. 357, 329-341.

[28] Bouyo, M.H., Zhao, Y., Penaye, J., Zhang, S.H., Njel, U.O., 2015. Neoproterozoic subduction-related metavolcanic and metasedimentary rocks from the Rey Bouba Greenstone Belt of north-central Cameroon in the Central African Fold Belt: new insights into a continental arc geodynamic setting. Precambrian Research 261, 40-53.

[29] Banakeng, L.A., Zo'o Zame, P., Tchameni, R., Mamdem, L., Bitom, D., 2016. Mineralogy and geochemistry of laterites developed on chlorite schists in Tcholliré region, North Cameroon. Journal of African Earth Sciences 119, 264-278.

[30] Pouclet, A., Vidal, M., Doumnang, J.-C., Vicat, J.-P., Tchameni, R., 2006. Neoproterozoic crustal evolution in Southern Chad: PanAfrican ocean basin closing, arc accretion and late- to postorogenic granitic intrusion. Journal of African Earth Sciences 44, 543-560.

[31] Toteu, S.F., Penaye, J., Deloule, E., Van Schmus, W.R., Tchameni, R., 2006. Diachronous evolution of volcano-sedimentary basins nord of the Congo craton: insights from U-Pb ion microprobe dating of zircon from the Poli, Lom and Yaoundé Groups (Cameroon). Journal of African Earth Sciences 44, 428-442.

[32] Cornachia, M., Dars, R., 1983. Un trait structural majeur du continent africain: les linéaments centrafricain du Cameroun au golfe d'Aden. Bulletin de la Société Géologique de France 25, 101-109.

[33] Almeida, F.F.M., Hasui, Y., Neves, B.B.B., Fuck, R.A., 1981. Brazilian structural provinces: an introduction. Earth Sciences Review 17, 291-317.

[34] Penaye, J., Toteu, S.F., Tchameni, R., Van Schmus, W.R., Tchakounté, J., Ganwa, A., Miyem, D., Nsifa, E.N., 2004. The 2.1 Ga West Central African Belt in Cameroon: extension and evolution. Journal of African Earth Sciences 39, 159-164.

[35] Ganwa, A.A., Frisch, W., Siebel, W., Ekodeck, G.E., Shang, C.K., Ngako, V., 2008a. Archean inheritances in the pyroxeneamphibole bearing gneiss of the Méiganga area (Central North Cameroon): Geochemical and ${ }^{207} \mathrm{~Pb} /{ }^{206} \mathrm{~Pb}$ age imprints. Comptes Rendus Geoscience 340, 211-222.

[36] Ganwa, A.A., Frisch, W., Siebel, W., Shang, C.K., Mvondo Ondoa, J., Satir, M., TchakountéNumbem, J., 2008b. Zircon ${ }^{207} \mathrm{~Pb} /{ }^{206} \mathrm{~Pb}$ evaporation ages of Panafrican metasedimentary rocks in the Kombé-II area (Bafia Group): Contraints on protoliths age and provenance. Journal of African Earth Sciences 51, 77-88.

[37] Ganwa, A.A., Frisch, W., Siebel, W., Shang, C.K., 2011. Geochemistry of Magmatic Rocks and Time Constraints on Deformational Phases and Shear Zone Slip in the Méiganga Area, Central Cameroon. International Geology Review 53, 759-784.

[38] Ganwa, A.A., Klötzli, U.S., Hauzenberger, C., 2016. Evidence for Archean inheritance in the pre-Panafrican crust of Central Cameroon: Insight from zircon internal structure and LA-MCICP- MS U-Pb ages. Journal of African Earth Sciences 120, 12-22.

[39] Bouyo Houketchang, M., Toteu, S.F., Deloule, E., Penaye, J., Van Schmus, W.R., 2009. U-Pb and Sm-Nd dating of high-pressure granulites from Tcholliré and Banyo regions: Evidence for a PanAfrican granulite facies metamorphism in north-central Cameroon. Journal of African Earth Sciences 54, 144-154.

[40] Bouyo Houketchang, M., Penaye, J., Barbey, P., Toteu, S.F., Wandji, P., 2013. Petrology of high-pressure granulite facies metapelites and metabasites from Tcholliré and Banyo regions: Geodynamic implication for the Central African Fold Belt (CAFB) of north-central Cameroon. Precambrian Research 224, 412-433.

[41] Soba, D., Michard, A., Toteu, S.F., Norman, D.I., Penaye, J., Ngako, V., Nzenti, J.P., Dautel, D., 1991. Données géochronologiques nouvelles ( $\mathrm{Rb}-\mathrm{Sr}$, U-Pb et $\mathrm{Sm}-\mathrm{Nd}$ ) sur la zone mobile panafricaine de l'Est Cameroun : âge protérozoïque supérieur de la série de Lom. Compte Rendu de l'Académie des Sciences, Paris 312, 1453-1458.

[42] Toteu, S.F., Van Schmus, W.R., Penaye, J., Michard, A., 2001. New U-Pb, and Sm-Nd data from Nord-Central Cameroun and its bearing on the pre - Pan-African history of Africa. Precambrian Research 108, 45-73.

[43] Tchameni, R., Pouclet, A., Penaye, J., Ganwa, A.A., Toteu, S.F., 2006. Petrography and geochemistry of the Ngaoundéré Pan-African granitoïds in Central North Cameroon: Implications 
for their sources and geological setting. Journal of African Earth Sciences 44, 511-529.

[44] Nkoumbou, C., Barbey, P., Yonta-Ngouné, C., Paquette, J.L., Villiéras, F., 2014. Pre-collisional geodynamic context of the southern margin of the Pan-African fold belt in Cameroon. Journal of African Earth Sciences 99, 245-260.

[45] Tchakounté J., Eglinger A., Toteu S.F. Zeh a., Nkoumbou C., Mvondo-Ondoa J., Penaye P., De Wit M., Barbey P., 2017. The Adamawa-Yadé domain, a piece of Archaean crust in the Neoproterozoic Central African Orogenic belt (Bafia area, Cameroon). Precambrian Research 299, 210-229.

[46] Hobbs, B.E., Means, W.D., Williams, P.F., 1976. An Outline of Structural Geology. New York, J Wileys and Sons, 379p.

[47] Ragan, D.M., 1973. Structural geology: an introduction to geometrical techniques. $2^{\text {nd }}$ edition, John Wiley and Sons, New York, pp. 1-208.

[48] Naïmou, S., Ganwa, A.A., Urs, K., Amadou D.K., Ekodeck G.E., 2014. Petrography and Geochemistry of Precambrian Basement Straddling the Cameroon-Chad Border: The Touboro-Baïbokoum Area. International Journal of Geosciences 5, 418-431.

[49] Ferré, E., Deleris, J., Bouchez, J.L., Lar, A.U., Peucat, J.J., 1996. The Pan-African reactivation of Eburnean and Archean provinces in Nigeria; structural and isotopic data. Journal of Geology and Mining Research 153, 719-728.

[50] Hanmer, S., 1986. Asymmetrical pull-aparts and foliation fish as kinematic indicadors. Journal of Structural Geology 8, 111-122.

[51] Goldstein, G.A., 1988. Factors affecting kinematic interpretation of asymmetric boudinage in shear zones. Journal of Structural Geology 10, 707-715.

[52] Ganno, S., Nzenti, J. P., Ngnotue, T., Kankeu, B., Kouankap Nono, G. D., 2010. Polyphase deformation and evidence for transpressive tectonics in the Kimbi area, Northwestern Cameroon Pan-African fold belt. Journal of Geology and Mining Research 2(1), 001-015.

[53] Tikoff, B., Fossen, H., 1998. Extended models of Transpression and transtension, and application to tectonic settings. Geological Society, London, Spec. Publ. 135, 15-33.

[54] Kankeu, B., Greiling, R.O., Nzenti, J.P., 2009. Pan-african strikeslip tectonics in eastern Cameroon-Magnetic fabrics (AMS) and structure in the Lom basin and its gneissic basement. Precambrian Research 174, 258-272.

[55] D'Lemos, R.S., Brown, N., Strachan, R.A., 1992. Granite magma generation, ascent and emplacement within a transpressional orogen. Journal of Geological Society of London 149, 487-490.
[56] Denèle, Y., Olivier, P., Gleizes, G., 2008. Progressive deformation of a zone of magma transfer in a transpressional regime: The Variscan Mérens shear zone (Pyrenees, France). Journal of Structural Geology, 30, 1138-1149.

[57] Nnange, J.M., 1991. The crustal structure of the Cameroon Volcanic Line and the Foumban shear zone based on gravity and aeromagnetic data. PhD thesis, University of Leeds, England, 242p.

[58] Hutton, D.H.W., Reavy, R.J., 1992. Strike-slip tectonics and granites petrogenesis. Tectonics 11, 960-967.

[59] Woodcock, N., Schubert, C., 1994. Continental strike-slip tectonics. In: Hancock, P.L (Ed.), Continental deformation. Pergamon Press, New York, pp. 251-263.

[60] Cobbold, P.R., Gapais, D., Rossello, E.A., 1991. Partitioning of transpressive motions within a sigmoidal fold belt: the Variscan Sierras Australes, Argentina. Journal of Structural Geology 13: 743-758.

[61] Jones, R.R., Tanner, P.W.G. 1995. Strain partitioning in transpression zones. J. Struct. Geol. 17: 793-802.

[62] Tikoff, B, De Saint Blanquatt, M (1997). Transpressional shearing and strike-slip partitioning in the late Cretaceous Sierra Nevada magmatic arc, California. Tectonics 16: 442-459.

[63] Dewey, J.F., Holdsworth, R.E., Strachan, R.A., 1999. Transpression and transtension zones. In: Holdsworth, R. E., Strachan, R. A. \& Dewey, J.F. (eds) Continental Transpressional and Transtensional Tectonics. Geological Society, London, Spec. Pub. 135, 1-14.

[64] Carosi, R., Frassi, C., Iacopini, D., Montomoli, C., 2005. Post collisional transpressive tectonics in northern Sardinia (Italy). $J$. Virtual Explo. 19(3): 2.

[65] Dabo, M., Gueye, M., Ngom, P.M., Diagne, M., 2008. Orogenparallel tectonic transport: transpression and strain partitionning in the Mauritanides of NE Senegal. In: Ennih, N \& Liégeois, JP. (eds) The Boundaries of West African Craton. Geological Society, London, Spec. Pub. 297: 483-497.

[66] Dawaï, D., Tchameni, R., Bascou, J. Awe Wangmene, S., Fosso Tchunte, P.M., Bouchez, J.L., 2017. Microstructures and magnetic fabrics of the Ngaoundéré granite pluton (Cameroon): Implications to the late-Pan-African evolution of Central Cameroon Shear Zone. Journal of African Earth Sciences 129, 887-897.

[67] Njome, M.S., Suh C.E., 2005. Tectonic evolution of the Tombel graben basement, southwestern Cameroon. Episodes 2, 37-41. 